\title{
Kultura intelektualna, wątpliwości metodologiczne i refleksja metapedagogiczna w rozwijaniu teorii i praktyki edukacji międzykulturowej
}

Streszczenie: Troska o kulturę intelektualną wydaje się stanowić jeden z elementarnych wymiarów rzetelnego rozwijania teorii i praktyki edukacji międzykulturowej. Troska o doskonalenie kultury intelektualnej - tak w wymiarze indywidualnym, nabywania i rozwijania sprawności poznawczych, jak i w wymiarze społecznym, zwłaszcza w zakresie pracy naukowej - dotyczy w szczególności rozwijania kultury logicznej i pogłębiania refleksji metodologicznej, podnoszącej wątpliwości i pozwalającej na krytyczne rozpoznanie problematyki badań. W tym ujęciu kultury intelektualnej, które w wykładzie „O kulturze logicznej” przedstawił Tadeusz Czeżowski, kultura intelektualna jest sprzęgnięta z teorią i praktyką edukacji międzykulturowej, gdyż „wznosi ludzi ponad dzielące ich przeciwieństwa i łączy ich węzłami ogólnoludzkiej solidarności”, a tym samym pozwala osiągać także te cele, które stawiane są przed edukacją międzykulturową.

Kształtowanie kultury intelektualnej, jako czynienie człowieka „wrażliwym na prawdę i fałsz, na poprawność myślenia i błędy logiczne”, odnosi wprost do dyskutowanej na gruncie edukacji międzykulturowej kwestii radykalizującego się i wypierającego inne stanowiska relatywizmu, który podaje w wątpliwość wartość prawdy i trafność odwołujących się do niej kryteriów poprawności myślenia. Mogą się wszakże nasuwać pytania: Czy takie rozumienie kultury intelektualnej (przy założeniu jej uniwersalności), które proponuje Czeżowski, nie jest formą (ukrytego) imperializmu kulturowego w sferze wartościowania wiedzy i edukacji oraz nie stanowi narzucania innym określonego zestawu wartości jako wartości niejako samo przez się oczywistych i obowiązujących? Czy można bowiem zasadnie i przekonująco wykazać, iż występują wspólne elementy kultury intelektualnej w różnych, także zdecydowanie odmiennych, formacjach kulturowych, elementy pełniące równie istotną rolę w obcych sobie tradycjach edukacyjnych, czy też zaprezentowane rozumienie kultury intelektualnej - jako moralnie zobowiązującej kultury logicznej - jest tylko przejawem jednej z wielu lokalnych formacji kulturowych, choć przedstawiającej się tak, jakby była ona - wraz z prawidłami logiki - czymś powszechnie ważnym i samo przez się zrozumiałym, a nawet czymś wpisanym w ludzką naturę lub ludzki umysł? Te (i podobne im) pytania nasuwają się 
tutaj, gdyż jedną z właściwości edukacji międzykulturowej jest, iż wychodzi ona na pogranicza, na których stykają się z sobą odmienności, i problematyzuje - postrzega wraz z innymi porównawczymi naukami o kulturze jako problematyczne - to, co w innych obszarach badań pedagogicznych uchodzi bądź uchodziło za wręcz nienaruszalną oczywistość danej kultury, której jako swoistego pewnika nie poddaje się pod dyskusję.

Słowa kluczowe: teoria edukacji międzykulturowej, kultura intelektualna, wątpliwości metodologiczne, refleksja metapedagogiczna, relatywizm, kultura logiczna

Godne odnotowania jest coraz silniejsze dążenie badaczy zagadnień edukacji międzykulturowej, aby przezwyciężyć osobliwy ateoretyczny model badań. Pedagogika jako dyscyplina, a wraz z nia badacze [...] zagadnień [z zakresu edukacji międzykulturowej], przeżywaja etap nowego określenia własnej tożsamości naukowej. Zabiegom tym towarzysza spory o teoretyczne modele rozumienia i uprawiania pedagogiki.

Tadeusz Lewowicki (2001, s. 160)

Wcią̇ [...] poszukujemy teorii przydatnych $w$ badaniach dotyczacych edukacji międzykulturowej. Wiele racji jest w przekonaniu, że »nie ma nic bardziej praktycznego od dobrej teorii«. Niech więc teorie stużą zarówno badaniom, jak i praktyce edukacji

międzykulturowej. Tadeusz Lewowicki, Ewa Ogrodzka-Mazur (2001, s. 12)

Kultura intelektualna czyni tego, kto ją nabyt, wrażliwym na prawdę i fatsz, na poprawność myślenia i btędy logiczne, budzi [...] sumienie logiczne, które jest podstawa krytycyzmu wobec siebie, tak jak wobec innych osób. Ten krytycyzm [...] pozwala wznieść sie ponad to, co zamaca stronniczymi momentami rzeczowość stanowiska i przezwyciężyć dogmatyczne zacietrzewienie [...]. Wznosi ludzi ponad dzielace ich przeciwieństwa i łączy ich węzłami ogólnoludzkiej solidarności. Tadeusz Czeżowski (1958, s. 278)

Troska o kulturę intelektualną wydaje się stanowić jeden z elementarnych wymiarów rzetelnego rozwijania teorii i praktyki edukacji międzykulturowej. Dotyczy to zwłaszcza rozumienia znaczenia i funkcji kultury intelektualnej w sytuacji zróżnicowania kulturowego (również stawiania pytań o zasadność uniwersalnych roszczeń dominujących form kultury intelektualnej) oraz odpowiednich zasad i praktyki kształtowania kultury intelektualnej w złożonych relacjach międzykulturowych (uchodzącej w wielu opiniach za jeden z warunków osiągania dobrostanu tych relacji). Edukacja międzykulturowa, sku- 
piając bowiem swą uwagę w głównej mierze na badaniu i kształtowaniu relacji międzykulturowych oraz na różnych aspektach (kulturowo odmiennych) czynności i procesów kulturotwórczych i na zespolonych z nimi wartościach, niejako ze swej natury uwagę kieruje na kulturę intelektualną i obiera ją za jeden z rozpatrywanych na jej gruncie problemów badawczych (ze swego punktu widzenia problematyzuje ją, m.in. wysuwa i analizuje różnego rodzaju wątpliwości). Prowadząc tak ukierunkowane dociekania, edukacja międzykulturowa - rzec można, że samozwrotnie - podejmuje zarazem krytyczną refleksję metapedagogiczną nad sposobem, w jaki jest i w jaki powinna być uprawiania, refleksję nad kulturą intelektualną (kulturą metodologiczną), która powinna jej towarzyszyć i wraz z nią (wewnątrz niej) się rozwijać.

\section{Doskonalenie kultury intelektualnej a kontekst odmienności i relacji międzykulturowych}

Troska o doskonalenie kultury intelektualnej - tak w wymiarze indywidualnym, nabywania i rozwijania sprawności poznawczych, jak i wymiarze społecznym, zwłaszcza działalności wiedzotwórczej społeczności naukowej - dotyczy w szczególności rozwijania kultury logicznej i pogłębiania refleksji metodologicznej, podnoszącej wątpliwości i pozwalającej na krytyczne rozpoznanie problematyki badań. Co więcej, w tym ujęciu kultury intelektualnej, które (w przytoczonej jako motto wypowiedzi) przedstawił - w wykładzie „O kulturze logicznej” na zebraniu Katedry Pedagogiki UMK w Toruniu 21 lutego 1954 roku$^{1}$ - znamienity filozof, metodolog i aksjolog, zarazem nauczyciel wielu pokoleń polskich humanistów, Tadeusz Czeżowski (1889-1981)2, odpowiednio kształtowana kultura intelektualna jest wyraźnie sprzęgnięta z teorią i praktyką edukacji międzykulturowej, gdyż „wznosi ludzi ponad dzielące ich przeciwieństwa i łączy ich węzłami ogólnoludzkiej solidarności", a tym samym pozwala osiągać także te cele, które stawiane są

1 Odnotować należy, iż wcześniejszy wykład na zebraniu Katedry Pedagogiki UMK w Toruniu Czeżowski wygłosił pt. O dyskusji i dyskutowaniu (21 grudnia 1953 roku), zob. Czeżowski, 1958, ss. 280-289.

2 O Tadeuszu Czeżowskim jako nauczycielu zob. W. Szulakiewicz, Tadeusz Czeżowski - nauczyciel w stużbie uniwersytetu (2014, ss. 147-194); o poglądach Czeżowskiego zob. D. Łukasiewicz 2002; R. Kleszcz 2002, ss. 67-78; ważnym świadectwem jest tekst Izydory Dąmbskiej Tadeusz Czeżowski - jedność dzieła i osobowości (1977, ss. 21-26); ze swej aktywności pedagogicznej T. Czeżowski zdaje sprawę we Wspomnieniach (zapiskach do autobiografii) (1977, ss. 427-440). 
przed edukacją międzykulturową. Troska o kulturę intelektualną, jako troska o odpowiednio uformowane „sumienie logiczne, które jest podstawą krytycyzmu wobec siebie, tak jak wobec innych osób”, o właściwie rozwinięty krytycyzm, który „pozwala wznieść się ponad to, co zamąca stronniczymi momentami rzeczowość stanowiska i przezwyciężyć dogmatyczne zacietrzewienie" ${ }^{3}$, zdaje się sytuować u źródeł edukacji międzykulturowej i u jej podstaw, pozwalając się jej ukonstytuować we właściwej dla niej postaci wśród nauk humanistycznych, dookreślając jej teoretyczną tożsamość wśród dziedzin pedagogiki, gdy mierzy się ona z kolejnymi wyzwaniami. Troska o kulturę intelektualną zdaje się także wydatnie sprzyjać należytemu spełnianiu praktycznych zadań edukacji międzykulturowej.

Kształtowanie kultury intelektualnej, jako czynienie człowieka „wrażliwym na prawdę i fałsz, na poprawność myślenia i błędy logiczne”, odnosi wprost do dyskutowanej na gruncie edukacji międzykulturowej kwestii radykalizującego się i wypierającego inne stanowiska relatywizmu, który podaje w wątpliwość wartość prawdy i trafność odwołujących się do niej kryteriów poprawności myślenia. Tej właśnie kwestii dotyczy uwaga, którą z punktu widzenia edukacji międzykulturowej dobitnie i w polemicznym trybie formułuje Jerzy Nikitorowicz: „Bardziej zagrażające i [...] częściej prowadzące do wykluczania, samowykluczania i marginalizacji są postawy radykalnego relatywizmu kulturowego i poprawności politycznej” (2013, s. 113)4. Radykal-

3 Podobnie rolę kultury logicznej postrzega Roman Ingarden (w tekście Rola logiki przy nauczaniu matematyki w szkole średniej, opublikowanym w 1936 roku w mającym znaczącą pozycję w pedagogice czasopiśmie „Muzeum”): „[...] kultura logiczna jest niezbędna dla wytworzenia samodzielnej kultury duchowej, a nie jest też bez znaczenia dla ukształtowania się charakteru, uległego nakazom rozumu. Umiar i rozsądek jest tylko tam możliwy, gdzie umysł jest należycie zdyscyplinowany prawami logiki i wprawiony do jasnego i ścisłego myślenia przez całe lata konsekwentnego ćwiczenia" (1936). Zob. też wypowiedź Izydory Dąmbskiej w sprawie nauczania logiki przy sposobności nauczania języka polskiego (1930).

4 Nikitorowicz zdecydowanie stwierdza: „Uważam, że obecnie idee wielokulturowości przeżywają kryzys głównie w kontekście wykreowanych i realizowanych w cywilizacji Zachodu zasad liberalizmu, relatywizmu kulturowego i poprawności politycznej, które to w efekcie prowadzą do wykluczania tożsamościowego i marginalizacji nie tylko imigrantów, ale także obywateli kraju ich przyjmującego. Bezrefleksyjne posługiwanie się kanonem relatywizmu i politycznej poprawności, uznanie wszystkich kultur za równe z pewnością było reakcją na negatywne zjawiska wcześniejszej dominacji, hegemonii, kolonializmu jednej kultury nad innymi" (2015, s. 27; zob. Nikitorowicz 2014, s. 174). 
ny relatywizm kulturowy, eliminujący „wrażliwość na prawdę i fałsz”, stanowi więc przedmiot krytycznego namysłu edukacji międzykulturowej.

Jeśli wszakże przyjmie się stanowisko oparte na akceptacji słabszej lub tym bardziej - mocniejszej wersji relatywizmus ${ }^{5}$, to wówczas mogą nasuwać się pytania: Czy takie rozumienie kultury intelektualnej (przy założeniu jej uniwersalności), które proponuje Czeżowski, nie jest formą (ukrytego) imperializmu kulturowego w sferze wartościowania wiedzy i edukacji oraz nie stanowi narzucania innym określonego zestawu wartości (zwłaszcza wartości intelektualnych, epistemicznych i edukacyjnych oraz moralnych i utylitarnych) jako wartości niejako samo przez się oczywistych i obowiązujących (zobowiązujących)? Czy można bowiem zasadnie i przekonująco wykazać, iż występują wspólne (powszechne) elementy kultury intelektualnej w różnych, także zdecydowanie odmiennych, formacjach kulturowych, elementy pełniące równie istotną rolę w obcych sobie tradycjach edukacyjnych, czy też zaprezentowane rozumienie kultury intelektualnej - jako subtelnej i moralnie zobowiązującej kultury logicznej - jest tylko przejawem jednej z wielu lokalnych formacji kulturowych, choć przedstawiającej się tak, jakby była ona - wraz z promowanymi przez nią prawidłami logiki - czymś powszechnie ważnym i samo przez się zrozumiałym, a nawet czymś wpisanym w ludzką naturę lub ludzki umysł? Te (i podobne im) pytania nasuwają się tutaj, gdyż jedną z właściwości edukacji międzykulturowej jest, iż wychodzi ona na pogranicza, na których stykają się z sobą odmienności, i problematyzuje - postrzega wraz z innymi porównawczymi naukami o kulturze jako problematyczne - to, co w innych obszarach badań pedagogicznych uchodzi bądź uchodziło za wręcz nienaruszalną oczywistość danej kultury, której jako swoistego pewnika nie poddaje się pod dyskusję $e^{6}$ Tym samym podejmowaną przez siebie refleksją edukacja międzykulturowa porusza i dynamizuje całość pedagogiki, skłaniając inne dziedziny pedagogiki (dotychczas zespolone wyłącznie lub przede wszystkim z daną kulturą i przekazywaną w niej tradycją) do co najmniej uwzględnienia lub samodzielnego podjęcia tej problematyzującej, krytycznej i samokrytycznej refleksji na pograniczu różnych kultur. Uwzględnić przy tym należy kontekst dominacji „aksjologicznej wichrowa-

5 Wokół pytania „relatywizm: zagrożenia czy szansa?” koncentrują się dociekania Adama Chmielewskiego (1998, s. 28-58); zob. Adam Chmielewski 2014; Renata Ziemińska przybliża i analizuje spór relatywizmu z absolutyzmem na temat pojęcia prawdy (2009, ss. 299-314).

6 Zob. Zbyszko Melosik 2007 (m.in. o postmodernistycznych dylematach edukacji wielokulturowej). 
tości” i niepewności „płynnych” zapatrywań, właściwych dla czasów postnowoczesności wyzbytej z dotychczasowych (również klasycznych) wielkich metanarracji, kontekst, który w odniesieniu do sytuacji pedagogiki charakteryzuje Bogusław Śliwerski:

„W postnowoczesnej dobie, po upadku w społeczeństwach totalitarnych metanarracji, naukowcy społeczeństw otwartych, pluralistycznych przyjęli, że nie ma »jednej « metateorii, jakiegoś jednego metajęzyka w naukach społecznych czy humanistycznych, gdyż każda próba wyniesienia uniwersalnego projektu czy metanarracji ponad inne staje się nieuprawomocnioną interpretacją [...] oraz wolą zdobycia władzy. Żadna z ich interpretacji nie może być nadrzędna nad inną, nie ma też »lepszych «i «gorszych« teorii. Można jedynie zaakceptować istnienie osobistych, zdecentrowanych, heterologicznych i specyficznie lokalnych form prawdy, pośród których każda może być prawdą dla »innej wersji świata«. [...] także w naukach pedagogicznych trwa walka teoretycznych dyskursów o ich miejsce w »centrum «, która usytuowana jest w ramach krzyżujących się ze sobą kontinuów, wyznaczonych przez antynomie: obiektywizm - subiektywizm, uniwersalizm - relatywizm, adaptacja - transformacja, porządek - konflikt, wolne działanie strukturalne zniewolenie, neutralność aksjologiczna - wartości jako podstawa zaangażowania" (2015, ss. 26-27).

Edukacja międzykulturowa z jednej strony może czerpać impulsy i inspiracji dla swego rozwoju z tak ukazanej różnorodności „innych wersji świata”, sama wpisując się w jakiejś mierze w tak postrzeganą różnorodność, a zarazem programowo nie zadowalając się tylko konstatowaniem wielości współwystępujących obok siebie i pomnażających się „innych wersji świata” (każdej ze swymi odrębnymi „prawdami”), edukacja międzykulturowa staje przed tym trudniejszym zadaniem określenia własnej teoretycznej tożsamości (której rdzeniem jest decyzja aksjologiczna i normatywna o potrzebie przejścia od „naturalnej” wielokulturowości do pedagogicznie zreflektowanej międzykulturowości) oraz kształtowania postaw sprzyjających zawiązywaniu i rozwijaniu relacji międzykulturowych.

\section{Troska o kulturę intelektualną a wielokierunkowy rozwój edukacji międzykulturowej}

W potocznym myśleniu (sposobie wyrażania) utrwala się stereotyp, że czym innym jest teoria i odległa od życia „wzniosła kultura czystej acz abstrak- 
cyjnej teorii”, a czym innym jest praktyka i bliska życiu „powszednia kultura szarej acz konkretnej praktyki". Jakby to były dwa różne i oddzielone od siebie porządki kulturowe, wymagające dopiero zbliżenia i próby przerzucania między nimi jakiegoś łączącego je „mostu”, a przecież kształtowanie postaw służących zbliżeniu kultur i rozwijaniu relacji między nimi to jedna z podstawowych powinności edukacji międzykulturowej.

Jeśli w codzienności występuje taki wzmagający się podział, to uprawianie refleksji pedagogicznej i metapedagogicznej nad edukacją służącą kształtowaniu relacji międzykulturowych powinno być w pewnym sensie samozwrotne. Jeśli edukacja międzykulturowa ma być „w swej istocie” edukacja międzykulturową, ma być wnikliwym rozpoznawaniem i kształtowaniem różnorakich relacji międzykulturowych (a nie tylko ma być edukacją międzykulturowa „z nazwy”), to rozwijając ją - dzięki trosce o kulturę intelektualną, zwłaszcza o kształtowanie kultury logicznej i refleksji metodologicznej - trzeba konsekwentnie dbać o łączność między teorią i „kulturą teorii”, a praktyką i „kulturą praktyki”, aby nie stawały się one dwoma radykalnie odseparowanymi od siebie sferami aktywności kulturotwórczej.

Rozwijanie teorii i praktyki edukacji międzykulturowej powinno więc cechować się swoistym dynamizmem i sprzężeniem zwrotnym: postulowanym i w jakiejś mierze urzeczywistnianym przechodzeniem od zakładanej (częstokroć tylko na próbę) teorii do pożądanej praktyki i od praktyki wciąż wykazującej mniej lub bardziej poważne niedostatki do doskonalącej ją i zarazem doskonalącej się teorii.

W kontekście współczesnych przemian cywilizacyjnych (naukowo-technicznych) do zadań edukacji międzykulturowej można także przypisać rozpoznawanie i kształtowanie relacji między co najmniej trzema oddalającymi się od siebie i zatracającymi punkty styczne kulturami: kulturą nauki (nauk przyrodniczych i formalnych oraz współcześnie rozwijającej się technonauki, także w obszarze bezpośrednio dotykających człowieka nauk, technik i praktyk medycznych7), kulturą humanistyczną (jako wiedzą i praktyką ukierunkowaną na troskę o swoiste wartości człowieczeństwa) i kulturą religijną (uwzględniającą w szczególny sposób to, co absolutne, i transcendencję przekraczającą wyłącznie ludzki świat) ${ }^{8}$.

7 O technonauce w społeczeństwie ryzyka i analizie niepożądanych następstw praktycznego sukcesu nauki zob. E. Bińczycka, 2012.

8 O rozmijaniu się i zderzaniu (a także szansach zbliżenia) trzech kultur: nauk przyrodniczych, humanistyki i myśli chrześcijańskiej zob. J. Życiński, 1990. 
Troska o kulturę intelektualną w rozwijaniu edukacji międzykulturowej sprzęga się też z „palącymi” zadaniami, które stawia się przed refleksją pedagogiczną dotyczącą trafnego rozpoznawania i odpowiedniego kształtowania relacji międzykulturowych: „Dotychczasowe doświadczenia w zakresie badań nad wielokulturowością coraz bardziej upewniają w tym, że szczególnie istotnym problemem jest potrzeba - jak ze znawstwem zagadnienia stwierdza Nikitorowicz - wypracowania nowej koncepcji kultury wiedzy o sobie i innych, co może i powinna podjąć edukacja międzykulturowa” (2012, s. 48). Ta powinność badawcza, wymagająca wykazania się wysoką kulturą intelektualną, a w szczególności krytycyzmem, który „pozwala wznieść się ponad to, co zamąca stronniczymi momentami rzeczowość stanowiska i przezwyciężyć dogmatyczne zacietrzewienie" ${ }^{9}$, dotyczy spraw fundamentalnych dla rozwoju teorii i praktyki edukacji międzykulturowej. Trzeba przy tym pamiętać o trafnym zaleceniu metodologicznego rygorysty, Leona Koja ${ }^{10}$, aby biorąc pod uwagę „nieokreśloność rozważań, w miarę możliwości tak jasno sprawę przedstawić, by błędy, których nie dostrzega autor, mogły być jawne dla innych i żeby dało się ustalić, co można zrobić, aby je wyeliminować". Uwzględniając swoiste dążenia edukacji międzykulturowej, trzeba wyeksponować wartość i niezbędność zmierzania do tego, aby była możliwa jawność błędów dla innych, gdyż inni z ich (odmiennego) punktu widzenia mogą dostrzegać te walory i te słabości, które dla autora pozostają niezauważalne. Tylko w ten sposób może powstawać i być doskonalona nowa koncepcja kultury wiedzy o sobie i innych.

Dociekania i badania służące wypracowaniu postulowanej nowej koncepcji kultury wiedzy o sobie i innych powinny też - zwłaszcza w towarzyszącej im metarefleksji - uwzględniać uwarunkowania, w których się dokonują, a wśród nich w szczególności ludzką kondycję poznawczą. Na istotny aspekt tych uwarunkowań uwagę zwraca Karl Raimund Popper w Logice

9 „Są ludzie mający ciasne schematy poznawcze, których jednak trzymają się kurczowo i na siłę wszystko w nie wtłaczają, byle tylko móc każdą sytuację zaliczyć do jednej z tych kategorii. Daje im to poczucie opanowania poznawczego rzeczywistości. Są jednak też schematy poznawcze szerokie i uniwersalne, ułatwiające przyjmowanie nowych elementów rzeczywistości. Właściwie nauczana logika formalna wyposaża właśnie w schematy najwygodniejsze, najbardziej uniwersalne i ułatwiające poznanie" (Grzegorczyk, 1993, s. 123).

10 „Przy całej nieokreśloności rozważań pragnę w miarę możliwości tak jasno sprawę przedstawić, by błędy, których ja nie widzę, były jawne dla innych i żeby dało się ustalić, co można zrobić, aby je wyeliminować" (Koj, 1998, s. 27). 
nauk społecznych: „[...] nie możemy pozbawić naukowca jego stronniczości nie pozbawiając go także jego człowieczeństwa. [...] nie możemy zakazać lub niszczyć jego ocen, nie niszcząc go jako człowieka i jako naukowca. Nasze motywy i nasze czysto naukowe ideały, takie jak ideał czystego poszukiwania prawdy, są głęboko zakorzenione w pozanaukowych i częściowo religijnych ocenach. Obiektywny i wolny od wartościowania naukowiec nie jest idealnym naukowcem. Bez pasji niczego nie możemy osiągnąć, a tym bardziej w czystej nauce. Słowo »umiłowanie prawdy« to nie tylko metafora" (1997a, s. 93). Dojrzała kultura intelektualna jest niezbędna, aby uprawiając edukację międzykulturową umiejętnie i w zreflektowany sposób godzić z sobą własną stronniczość i własne oceny, będące wyrazem człowieczeństwa, z dążeniem do przekraczania tej stronniczości i tych ocen, aby kształtować relacje międzykulturowe, relacje z tymi, którzy mają także własną stronniczość i własne oceny, będące wyrazem ich człowieczeństwa. Dlatego w tej sytuacji jak najbardziej pożądana jest wytwarzająca dystans wobec stronniczości refleksja metodologiczna poszukująca tego, co w jakiejś choć mierze przekracza stronnicze oceny, aby móc rozwijać teorię i praktykę edukacji międzykulturowej.

Kwestię praktycznej przydatności badań metateoretycznych i metodologicznych można ująć zgodnie z dictum: nie ma nic bardziej praktycznego od rzetelnie sformułowanej teorii (metateorii) i nie ma nic bardziej szkodliwego dla działań praktycznych niż brak odpowiedniej teorii (metateorii), gdyż nie wypracowując jej, działa się po omacku i bez pogłębionej świadomości tego, co się faktycznie czyni. Uwzględnić przy tym też należy edukacyjny (dydaktyczny, autodydaktyczny) wymiar analiz metodologicznych i refleksji metateoretycznej, które towarzysząc uprawianiu danej dziedziny nauki, pozwalają uczyć się jej „od wewnątrz” i dzięki temu uczeniu się zachować jej otwartość na nowe - doniosłe poznawczo lub doniosłe praktycznie - sytuacje problemowe.

Aksjologiczne uwikłania teoretycznych dociekań i badań w zakresie edukacji międzykulturowej wiążą się z ogólniejszą kwestią relacji między wartościami: między uzyskaną rzetelną wiedzą a faktycznym czynieniem dobra. Z jednej strony „wiedza, zdobywanie mądrości oraz rozpoznawanie dobra i dążenie do dobra, choć nie identyczne, są ze sobą powiązane i wzajemnie uwarunkowane. Wiedza jest dobrem - zdobywając ją, stajemy się lepsi. Zdobywając wiedzę z nastawieniem ku dobru - zdobywamy ją lepiej. Ale - jak realistycznie stwierdza Michał Heller - jest to sytuacja wyidealizowana [...]. Ludzka wolność działania może i w tej dziedzinie spowodować wielkie dewastacje. Wiedzę można nawet przeciwstawić dobru i użyć jej w złym celu" 
(2009, s. 11). Wiedzę o tym, jak przebiegają relacje międzykulturowe, co je determinuje i jak je da się kształtować, można wykorzystać do tego, aby osłabiać albo wzmagać antagonizmy międzykulturowe, aby ludzi z sobą jednoczyć albo ich sobie przeciwstawiać. Przed moralnie i praktycznie niepożądanymi skutkami podejmowanych dociekań i badań, które nie są odpowiednio pod względem moralnym rozeznane, zdecydowanie przestrzega Popper: „my - intelektualiści - jesteśmy winni niemal całej nędzy, ponieważ zbyt mało walczymy o intelektualną uczciwość" (1997c, s. 113). Bez tej elementarnej uczciwości nie będzie się rozwijała edukacja międzykulturowa, a zachowaniu i umacnianiu tej uczciwości ma w pierwszym rzędzie służyć kształtowanie kultury intelektualnej, dostrzeganie wątpliwości metodologicznych i pogłębianie refleksji metapedagogicznej zespolone z uprawianiem edukacji międzykulturowej ${ }^{11}$.

\section{O potrzebie analiz metodologicznych i refleksji metateoretycznej w uprawianiu edukacji międzykulturowej}

Z historii nauki - zwłaszcza w XX wieku - można zaczerpnąć przykłady sporów dotyczących potrzeby intensyfikacji analiz metodologicznych i refleksji metateoretycznej, które - jak deklarują ich promotorzy - mają przyczyniać się do rozwoju (postępu poznawczego) w danej dziedzinie wiedzy. Wysuwano bowiem argumenty za i przeciw rozbudowywaniu analiz metodologicznych i refleksji metateoretycznej. Nieco ironizując, stwierdza się, że w niektórych dyscyplinach i subdyscyplinach doszło do tego, że prowadzono przede wszystkim debaty skupione wokół pytań o to, jak właściwie uprawiać te dyscypliny, ale czyniono to takim kosztem, że prawie zaniechano samego ich uprawiania. W sposobie wyrażania niektórych stanowisk w debatach metaprzedmiotowych upatrywano też wzmożoną retorykę walki, przesłaniającą racje merytoryczne (które powinny być pierwszoplanowe), retorykę służącą głównie apologetycznej obronie własnych wyborów ideowych i promocji własnych preferencji badawczych.

Jednak - mimo podnoszonych słusznych zastrzeżeń - w dociekaniach o charakterze humanistycznym - jak ujmuje to Tadeusz Kotarbiński w tekście Filozofia a humanistyka z 1972 roku - częstokroć spotyka się „przeróż-

11 O potrzebie i kierunkach rozwijania refleksji metapedagogicznej zob. B. Śliwerski (2014). 
ne zagadnienia niejako metarefleksyjne. Są to te, do których formułowania potrzebne okazują się nazwy samych właśnie aktów refleksji lub ich elementów... Więc do refleksji bezpośredniej nad literaturą będzie należało na przykład pojęcie komedii lub pojęcie sonetu, [...], natomiast takie nazwy, jak np. »muzykologia« lub »nauka o stylach « trzeba zaliczyć do pojęć z metarefleksji. Metarefleksyjne będą np. takie zagadnienia, jak zagadnienia możliwości stosowania introspekcji w humanistyce... [...] w dziełach humanistycznych ma się normalnie do czynienia z fluktuacją postaw wyżej wymienionych, na przykład zagadnień ideologicznych przeplatających się z zagadnieniami refleksji nad ideologią i nad sposobami badania stosowanymi w takiej refleksji. Kto by chciał, uprawiając humanistykę, trzymać się ściśle w każdym przypadku limitów któregokolwiek z wyróżnionych działów refleksji, postępowałby tak jak geodeta, który by chciał ustawiać w prądach morskich kopce graniczne na wzór obrzeżeń połaci stałego lądu" (1993, s. 94). Dociekania dotyczące zagadnień metarefleksyjnych są więc wpisane w dynamikę refleksji humanistycznej, w tym też refleksji pedagogicznej. W kontekście podjętej tu problematyki warte uwzględnienia są też uwagi Leona Koja o swoistości i ożywczej roli wątpliwości metodologicznych towarzyszących uprawianiu nauki i rozwijaniu - zespolonej z nimi - refleksji metodologicznej ${ }^{12}$.

Do wskazanego przez Tadeusza Lewowickiego - w tekście obranym tu za motto - „coraz silniejszego dążenia badaczy zagadnień edukacji międzykulturowej, aby przezwyciężyć osobliwy ateoretyczny model badań", można odnieść także uwagi i postulaty metafilozoficzne Stanisława Kamińskiego (filozofa, a zarazem metodologa nauk, nauczyciela kształtującego kulturę metodologiczną wielu pokoleń jego uczniów), które były przez niego formułowane w merytorycznie podobnej sytuacji dyscypliny, której teoretyczne

12 Zob. Leon Koj zatytułował zbiór swych rozpraw i szkiców: Watpliwości metodologiczne (1993). „Tytuł książki Leona Koja Wątpliwości metodologiczne może być rozumiany w dwojaki sposób. Najpierw może oznaczać ujawnianie wątpliwości w stosowanej metodologii nauk, ukazywanie w niej elementów nieuzasadnionych lub uzasadnionych w mniejszym stopniu, niż sądzono. W drugim znaczeniu tytuł ten może zapowiadać próby metodycznego posługiwania się wątpliwościami, budowanie metodologii nauk, która nie omija wątpliwości, ale stara się je wykorzystać, włączyć w strukturę nauki. Będą to więc już nie zwykłe wątpliwości, ale wątpliwości metodologiczne, czyli opracowane przez metodologie i wykorzystane w niej. Takie postępowanie z wątpliwościami można by nazwać tworzeniem jakiejś „metodologii wątpliwości”, która mogłaby stać się elementem metodologii nauk” - zauważa Zbigniew Wolak w recenzji tej książki (1994, s. 127). 
wzmocnienie i rozwój miał on na względzie. Zdecydowanie postulował przezwyciężanie ateoretyczności bliskiego mu stylu uprawiania filozofii:

„Często podkreśla się, że w XX w. dla każdego poważnego i samodzielnie myślącego badacza praktycznie niezbędne stało się odpowiednie »wyposażenie« logiczne i metodologiczne. Tym bardziej samowiedza metodologiczna konieczna jest każdemu, kto chce odpowiedzialnie filozofować".

Przytaczał następujące racje na rzecz rozwijania dojrzałej postaci samowiedzy metodologicznej, jako niezbędnego elementu odpowiedzialnych badań, które mają sprostać metodologicznym rygorom właściwym nauce:

„Z jednej strony bowiem niepodobna, aby filozof-specjalista choćby najbardziej przedmiotowo nastawiony i unikający jakiejkolwiek refleksji nad nauką i metodą mógł powstrzymać się od wypowiadania uwag o charakterze metateoretycznym i metodologicznym. Z drugiej zaś strony wszechstronna i rzetelna wiedza o metodzie filozofii dlatego jest niezbędna, iż poznanie filozoficzne sprawia szczególne trudności w jego zdobywaniu i uprawomocnianiu oraz komunikowaniu" (Kamiński, 1962, s. 37) ${ }^{13}$.

Aby nie stwarzać niepożądanego i błędnego wrażenia, iż idzie tu tylko o techniczną znajomość i umiejętność stosowania właściwych metod, Kamiński dopowiadał, że - ze względu na materię dociekań - wymagana jest też bieżąca i dociekliwa refleksja dotycząca m.in. wartości metod:

„nie chodzi przy tym o samą znajomość stosowanych metod filozofowania, ale także o zdawanie sobie sprawy z ich wartości epistemologicznej $\mathrm{i}$ to w porównaniu z metodami innych nauk. A wreszcie nie wolno zapominać również o tym, że tezy filozoficzne posiadają olbrzymią wagę teoretyczno-poznawczą oraz kolosalną doniosłość praktyczną. Zmusza to do tym większej troski o należyty sposób ich uzasadniania" (tamże) ${ }^{14}$.

13 Związany z tym samym nurtem filozofii co Kamiński, Antoni B. Stępień równie mocno podkreśla potrzebę kształtowania zdolności autoanalizy własnego poznania: „Ale nawet wtedy, gdy filozof nastawiony jest przedmiotowo, na dotarcie do istoty i ostatecznej racji bytu, nie ginie nigdy z pola jego zainteresowań zagadnienie wartości poznania, które uzyskuje. Filozof stara się poznawać z pełną świadomością charakteru swego poznania. Adept filozofii musi wyćwiczyć w sobie umiejętność trzeźwej, uważnej, równoległej do zajmowania się przedmiotami autoanalizy" (1995, s. 320).

14 Kamiński nie odmawia filozofii prawa do pełnienia również funkcji pozapoznawczych, jednak wymaga przestrzegania określonej hierarchii tych funkcji. Podej- 
Podobnie analizy, badania i tezy z edukacji międzykulturowej (pedagogiki międzykulturowej) „posiadają olbrzymią wagę teoretyczno-poznawczą oraz kolosalną doniosłość praktyczną", dlatego też wymagają one systematycznej i konsekwentnej refleksji metateoretycznej, czyli „samowiedzy metodologicznej" odpowiedzialnego pedagoga-badacza. Z tej racji można tu dokonać podstawienia i trawestacji: „niepodobna, aby pedagog-specjalista z edukacji międzykulturowej, choćby najbardziej przedmiotowo nastawiony i unikający jakiejkolwiek refleksji nad nauką i metodą, mógł powstrzymać się od wypowiadania uwag o charakterze metateoretycznym i metodologicznym", jak również „wszechstronna i rzetelna wiedza o metodzie uprawiania edukacji międzykulturowej (pedagogiki międzykulturowej) dlatego jest niezbędna, iż dokonujące się tu poznanie - wśród odmiennych kultur, systemów wartości i języków - sprawia szczególne trudności w jego zdobywaniu i uprawomocnianiu oraz komunikowaniu". Tak - może dość radykalnie - ukazana perspektywa rozwijania refleksji metateoretycznej towarzyszącej badaniom międzykulturowym powinna pozwolić na dalsze - postulowane m.in. przez Lewowickiego - przekraczanie „osobliwej ateoretyczności” badań w edukacji międzykulturowej.

Rozwój zdolności do samokontroli, samowiedzy i samooceny ma też wymiar autoedukacyjny, na który wskazuje Andrzej Grzegorczyk: „Działanie każdego człowieka zawiera wiele elementów wymykających się spod jego kontroli. Jednakże z biegiem lat uczymy się kontrolować coraz większą ilość momentów naszych zachowań. Kontrola oznacza zaistnienie samowiedzy, samooceny i związanej z nią decyzji. Działanie, w którym więcej elementów podlega kontroli, nazywamy bardziej przemyślanym" (1993, s. 122). Także w danej dziedzinie wiedzy ukierunkowanej teoretycznie lub praktycznie powinien następować rozwój jej samowiedzy metodologicznej, która wspiera (ocenia, koryguje) prowadzone przez nią badania przedmiotowe.

Dojrzałość badań w zakresie edukacji międzykulturowej skłania do intensyfikacji takich analiz metodologicznych, które współdziałają z uprawianą wewnątrz tych badań refleksją metateoretyczną. Na dość daleko idące zmiany, które postuluje i po części już wprowadza edukacja międzykulturo-

mowanie się przez filozofię funkcji pozapoznawczych podporządkowuje spełnianiu prymarnych funkcji poznawczych. Wysuwa nawet zasadę (która brzmi jako zalecenia formułowane w ramach etyki biznesu o praktycznych walorach uczciwości i zaufania): „funkcje pozapoznawcze tym będą obfitsze i cenniejsze, im bardziej zrealizują się poznawcze" (1993, s. 187). 
wa, zwraca uwagę Marian Nowak: „międzykulturowość jest rozumiana jako nowy model działalności wychowawczej - w odróżnieniu od innych modeli z przeszłości - wyznaczający nowe podstawy w relacjach międzyludzkich, co wymaga swoistej transformacji naszej wiedzy antropologicznej związanej z rozumieniem podmiotu, komunikowania i sposobów myślenia, i to zarówno w wymiarze praktyki wychowania, jak i w refleksji teoretycznej" (2012, s. 565). Tym bardziej jest więc niezbędna samowiedza metodologiczna, aby analizować zmiany w zakresie rozumienia podstawowych pojęć i w przebiegu refleksji teoretycznej.

Rozwijanie analiz metodologicznych i refleksji metateoretycznej powinno prowadzić do wychodzenia poza przekonania i wyrażające je formuły słowne (określane jako „paradygmaty”) właściwe danym wspólnotom uczonych (kolektywom myślowym). Powinien dokonywać się proces przekraczania wąskich punktów widzenia, zacieśniających ogląd (horyzont) poznawczy.

Dzięki wnikliwej i krytycznej refleksji metateoretycznej możliwe jest niejako zrzucanie lub zmienianie „teoretycznych okularów”, aby mieć nowy, świeży i odmienny dostęp do badanej rzeczywistości. Dokonuje się odkrywanie nowych - poznawczo owocnych i społecznie doniosłych - sytuacji problemowych i dynamizowanie badań przedmiotowych przez rozwijanie towarzyszących im analiz metodologicznych i refleksji metateoretycznej.

Refleksja metateoretyczna może być postrzegana również jako swoistego rodzaju sytuacja międzykulturowa i transkulturowa, bowiem dąży do krytycznego rozeznania różnych schematów i odmiennych modeli badawczych, funkcjonujących obok siebie i mimo siebie (jakby osobnych kultur), które same z siebie mogą pozostawać mniej lub bardziej zamknięte na potrzebę ich komparatystycznego ujęcia, prowadzącego do oceny ich wartości poznawczej i korekty.

Refleksja metodologiczna pozwala sformułować i wzmocnić epistemologiczno-metodologiczne argumenty na rzecz rozwijania edukacji międzykulturowej: wyeksponować fragmentaryczność i aspektowość ludzkiego poznania, ograniczoność i kulturowe zawężenie ludzkiego języka (języków etnicznych ukształtowanych w określonych warunkach społecznych), wyostrzyć postulaty mające skłaniać do przekraczania partykularnego poznania i dyskursu w dążeniu do rzetelnego i w miarę całościowego poznawczego ujęcia rozpatrywanej rzeczywistości. Rzetelna refleksja metodologiczna sprzyja przezwyciężaniu radykalnego zawężenia oglądu tylko do stanu określanego mianem „własnego punktu widzenia”, które daje być może spójny, ale za to dalece jednostronny ogląd złożonych sytuacji i relacji. 
Inny i Obcy z epistemologiczno-metodologicznego punktu widzenia mogą być postrzegani jako epistemologiczne wyzwanie dla możliwości intersubiektywnie sprawdzalnego (rzetelnego) poznania i intersubiektywnej komunikacji (a nie tylko pozostawania w ramach własnych schematów i stereotypów służących opisaniu i zarazem wartościowaniu tego, co jawi się jako inne i obce).

W refleksji metateoretycznej:

- dokonuje się odkrywanie (odsłanianie) założeń edukacji międzykulturowej, które nie są wprost wyartykułowane, a mogą zdecydowanie przesądzać o kierunku (intencji) przebiegu i wyniku podejmowanych przedsięwzięć badawczych w obszarze edukacji międzykulturowej;

- dokonuje się metodologiczna rekonstrukcja źródeł i przemian orientacji badawczych w edukacji międzykulturowej;

- rozpatruje się szanse, ograniczenia i trudności w wielodyscyplinarnym (inter-, trans-) podejściu do wieloaspektowej problematyki relacji międzykulturowych i prowadzenia badań z zakresu edukacji międzykulturowej, przy uwzględnieniu potrzeby kształtowania - teoretycznie dojrzałej i w jakimś zakresie też autonomicznej - pedagogiki międzykulturowej z jej własnym instrumentarium badawczym;

- rozpatruje się wątpliwości i dylematy metodologiczne dotyczące obecności elementów filozofii (założeń, problemów i metod filozoficznych) w edukacji międzykulturowej; przy czym uwzględnia się, że wątpliwości i dylematy metodologiczne stanowią swoistą grupę problemów (sytuacji problemowych) rozpatrywanych w metarefleksji.

\section{O możliwościach badania i porównywania kultur oraz przekraczania ich uwarunkowań}

Do refleksji metodologicznej, a zarazem do analiz relacji (i konsekwencji różnic) międzykulturowych skłaniają - jak się wydaje - pouczające - wnioski $\mathrm{z}$ badań Gebriela Abenda nad kulturowymi różnicami standardów metodologicznych z nauk społecznych i wskazanie na wyraźnie odmienne formułowanie problemów badawczych oraz uzyskiwanie odmiennych wyników przez socjologów meksykańskich i socjologów północnoamerykańskich ${ }^{15}$. Wojciech

15 Badania Gebriela Abenda przytacza i omawia W. Sitek: Paradygmaty, aporie i instytucjonalizacja socjologii w kontekście twórczości Floriana Znanieckiego (2010, ss. 133-142). 
Sitek stawia więc pytanie: „Co zatem powinniśmy robić, kiedy znajdziemy się w Meksyku, a uznajemy amerykańskie wzory uprawiania socjologii?” i w odpowiedzi przytacza opinię Floriana Znanieckiego (z jego Wstępu do socjologii): „Gdy zostaniemy przeniesieni do innego społeczeństwa, nasze przewidywanie jest bezskuteczne i nasze działanie bezpłodne o tyle właśnie, o ile schematy postępowania, narzucone jednostkom, są w tym społeczeństwie inne, niż w naszym" (tamże, s. 142). Jeśli wskazane różnice kulturowe (w tym też standardy metodologiczne) sięgają tak daleko, to można się nawet - zwłaszcza w tym kontekście - pokusić o prowokacyjnie sformułowane pytanie, dotyczące kulturowej „legalności” badań: czy północnoamerykański profesor socjologii (obarczony swym bagażem kulturowym i zespolonym z nim instrumentarium badawczym) może rzetelnie badać - geograficznie bliską, ale kulturowo zdecydowanie odległą - złożoną i jakby z zewnątrz nieprzeniknioną sytuację społeczną w Meksyku? Czy powinien to czynić jedynie zaangażowany w taką sytuację (zaangażowany niejako „od urodzenia” i „całym sobą") meksykański socjolog? Czy też może powinien to czynić i jeden, i drugi, zarazem prowadząc między sobą międzykulturową debatę, dyskusję - zwłaszcza w tym przypadku - jako niezbędną (a być może nawet uprzywilejowaną) metodę wiedzotwórczą?

\section{Edukacja międzykulturowa wobec błędu naturalistycznego}

Edukacja międzykulturowa powinna przy tym zmierzyć się z występowaniem błędu naturalistycznego i potrzebą jego rozpoznawania. Jak zauważa Władysław Stróżewski: „każda formacja kulturowa popełnia zrazu »błąd naturalistyczny«. Dlaczego tak się dzieje? Wydaje się, że można tu mówić o szczególnej fascynacji wartością nadrzędną, która, [...], jawić się może jako remedium na wszelkie nie zaspokojone dotąd potrzeby. Każda wielka wartość oślepia, każda może jednak zaślepić, jeśli nie zwróci się uwagi na jej jednostronność. »Błąd naturalistyczny« polega więc na nietrafnym rozeznaniu faktycznego stanu rzeczy, a więc na niewierności wobec idei prawdy. Ta zaś polega wszak na odsłonięciu istoty rzeczy, do ujrzenia jej pełni, gdy pełnia jej przysługuje, ale i jej ograniczeń, gdy nimi jest napiętnowana" (1992, s. 122). Metodologiczna samowiedza edukacji międzykulturowej powinna służyć również rozpoznawaniu i przezwyciężaniu błędu naturalistycznego, aby skutecznie przezwyciężać powodowaną przez niego - a zawężającą horyzonty poznawcze - jednostronność ujęcia i otwierać na wielowymiarowość zróżnicowanej rzeczywistości. 


\section{Metodologiczno-epistemologiczne perspektywy krytycznego racjonalizmu jako inspiracja dla teorii i praktyki edukacji międzykulturowej}

Z zasadniczych Popperowskich przekonań dla edukacji międzykulturowej ważne jest m.in. następujące metodologiczno-epistemologiczne zalecenie krytycznego racjonalizmu: „postawa rozumna [...] zakłada jakiś stopień intelektualnej pokory. Być może kierować się nią potrafią tylko ci, którzy wiedzą, że nieraz zdarzyło się im nie mieć racji i którzy zazwyczaj pamiętają o własnych błędach. Postawę taką rodzi świadomość, [...], że większość naszej wiedzy zawdzięczamy innym. Polega ona na stosowaniu [...] dwóch zasadniczych reguł postępowania sądowego: [...] należy wysłuchać obu stron, [...] nikt nie może być arbitrem we własnej sprawie. [...] Każda bowiem inna postawa - nawet jednostronna próba stosowania łagodnej perswazji i odwoływania się do argumentów, o absolutnej słuszności, których jesteśmy święcie przekonani - wiedzie do stosowania przemocy. Pamiętajmy, jak wiele wojen religijnych prowadzono w imię miłości bliźniego, ilu ludzi spalono na stosach w imię ratowania ich dusz przed wieczystym piekłem. Nadzieja na rozumne opanowanie aktów przemocy płynących z nabożności i poczucia obowiązku okaże się złudna, jeśli nie zrezygnujemy w sporach z postawy autorytarnej i nie będziemy gotowi uczyć się od innych" (Popper, 1999, ss. 592-593). Edukacja międzykulturowa nie tylko powinna badać i kształtować umiejętność uczenia się od innych, ale powinna ją uznawać za jedno z własnych principiów metodologicznych.

Edukacja międzykulturowa w swych badaniach i formułowanych zaleceniach praktycznych powinna - w sposób systematyczny i konsekwentny - uwzględnić walor konfliktów w relacjach między odmiennymi kulturami, na co zwraca uwagę Karl Raimund Popper w tekście $O$ zderzeniu kultur: „Społeczeństwo ludzkie potrzebuje pokoju, ale potrzebuje także poważnych ideowych konfliktów: wartości, idei, o które moglibyśmy walczyć. W naszym zachodnim społeczeństwie nauczyliśmy się - nauczyliśmy się tego od Greków - że w tych konfliktach można osiągnąć lepsze i bardziej trwałe wyniki nie tyle mieczem, ile słowami; a najlepiej z pomocą racjonalnych argumentów" (1997b, s. 142). Co więcej, Karl Raimund Popper uznaje, iż to Herodot ukazał już walory konfliktów w relacjach między odmiennymi kulturami: „Herodot, którego słusznie nazywa się ojcem historiografii, był czymś więcej niż tylko prekursorem nauki historii. Był właściwym odkrywcą krytycznego, oświeceniowego charakteru zderzenia kultur, a zwłaszcza kultur greckiej, 
egipskiej i medyjsko-perskiej. [...] [Herodot] pokazuje, iż „rozumny człowiek musi nauczyć się, że zakwestionowane mogą być także takie rzeczy, które z początku wydają mu się zupełnie zrozumiałe" (tamże, s. 146). W tym nurcie uformowała się też edukacja międzykulturowa, która wykazuje (podaje racje), że dzięki zetknięciu się odmiennych kultur można i powinno uczyć się poddawania pod rzetelną dyskusję (prezentującą i rozpatrującą różne punkty widzenia) te sprawy, które dotychczas (mocą własnej tradycji) uchodzą za sprawy ostatecznie rozstrzygnięte, niekwestionowalne i w pełni oczywiste. Co więcej, edukacja międzykulturowa powinna kształtować umiejętność uczenia się takiego podawania w wątpliwość (choćby na próbę), przechodzenia od mimowolnego przyjmowania „niewzruszonej oczywistości” do refleksyjnego podejścia, w którym ma się do czynienia z kwestią dyskutowaną i wielostronnie rozpatrywaną. Takiego podejścia trzeba się jednak w odpowiedni sposób uczyć, aby umieć przezwyciężać - bywa, że głęboko zakorzenione przyzwyczajenia i wychodzić poza dotychczasową siatkę pojęć. Perspektyw uczenia się rozpoznawania i przekraczania własnych oczywistości kulturowych dotyczy też uwaga, która sformułował Marian Nowak: „Destrukturyzacja pozwala pedagogowi międzykulturowemu na skierowanie spojrzenia ku własnej kulturze, w celu dokonania demontażu założeń koncepcyjnych i paradygmatycznych, które w sumie tylko wzmacniają redukcjonistyczne ujęcie kultury przez ludzi Zachodu, oparte na poczuciu wyższości” (2012, s. 573). Jak daleko ma sięgać ostrze destrukturyzacji, aby odchodząc od fałszującego obraz zróżnicowanej rzeczywistości redukcjonistycznego postrzegania zjawisk, zarazem wykształcić i zachować w sobie zdolność do intelektualnej konfrontacji - czyli do podmiotowego spotkania i dialogu - z odmiennymi kulturami, a nie stać się tylko jednostką lub społecznością bez kulturowo (aksjologicznie) określonych właściwości, która wchłania - bez filtrowania, rozeznania i oceniania - podawane jej z zewnątrz treści?

\section{Dyskusja jako metoda poznawcza i wiedzotwórcza w edukacji międzykulturowej}

O pozytywnej roli dyskusji i o różnieniu się jako jednym z warunków płodnej dyskusji pisał m.in. Zygmunt Mysłakowski: „W sądach o zdarzeniach i ludziach spotykamy na każdym kroku wielką różnorodność. I to jest rzeczą normalną i pożyteczną. Wszelki uniformizm i indoktrynacja (zaszczepianie przez nauczanie i propagandę tych samych formułek myślowych) jest rzeczą ryzykowną - nawet w Kościele, który to najczęściej uprawiał. Dlatego ktoś 
z mądrzejszych przedstawicieli tegoż Kościoła wyrzekł znamienne zdanie: haereses oportet esse, a także: »gnuśnieje dzielność bez sprzeciwu «. Dyskusja i swoboda w ukształtowaniu i formułowaniu zdań różniących się, a nawet przeciwnych sobie, jest warunkiem żywotności i dynamiczności życia umysłowego. Tylko głupcy chcieliby dla wygody zamienić życie umysłowe na jakiś automat w rodzaju szafy grającej. [...] Wszelki uniformizm prowadzi do wyjałowienia i zaniku zainteresowań" (1971, s. 245). Niestety, gdy dyskusja w nauce zanika, to "automat w rodzaju szafy grającej” staje się wzorcem w przygotowywaniu publikacji wyzbytych z wartości poznawczych i intelektualnych, publikacji, które wcześniej nie zostały wnikliwie przemyślane i przedyskutowane, a same nie są też punktem wyjścia do dalszego prowadzenia dyskusji wiedzotwórczej. Jak zauważa Lech Witkowski: „Każda żywa tradycja, każde żywe dziedzictwo istnieje, jeśli trwa w nich wielogłosowość i wielopostaciowość ich pamięci. Homogenizacja świata, charakterystyczna dla hegemonii, każdą tradycję zabija, zawłaszczając ją i redukując do wykładni narzuconej instytucjonalnie" (2007, s. 128). W dyskusji stawiającej sobie cele poznawcze należy uwzględnić postulat, który formułował Henryk Elzenberg: „Na cóż wszelkie myślenie [...] i mozół duchowy, jeśli nie prowadzą do przełamania i przegród i zapór stworzonych przez myśl cudzą, środowisko, tradycję, przesądy praktyki itp., i zetknięcia się z rzeczywistością o k o w o k o, spojrzenia na [...] świat własnym, nieuprzedzonym, niezmąconym spojrzeniem?" (1994, s.153).

Sztukę dyskutowania jako niezbędny element pracy naukowej rozpatruje i promuje Witold Marciszewski. Jest on przekonany, że z przedstawionych przez niego „rozważań etyczno-logicznych [dotyczących sztuki dyskusji] wyłania się idea dyskusji będącej podstawową działalnością poznawcząa". W tej działalności otwartość na krytykę własnych argumentów i racji jest zarazem otwartością na poznawcze zmierzenie się z nową sytuacją problemową: „,rozgrywana wedle reguł logiki konfrontacja przekonań, w której każda ze stron ma równe prawa krytykowania drugiej i równy obowiązek poddawania się krytyce” (1994, s. 63). Dyskusja wymaga, aby dyskutanci przedstawiali odmienne racje i różnili się między sobą. I taka właśnie dyskusja jest „inspiracją, źródłem pomysłów, bodźcem do osobistej twórczości” (tamże, s. 145). Co więcej, partnerzy dyskusji „obaj mogą mieć rację, każdy z innego punktu widzenia, pomimo pozornej sprzeczności w słowach" (tamże). Dzięki dyskusji bowiem „poznaje się inny świat myśli” (tamże), a można też przyjąć założenie, iż „każdy umysł odzwierciedla w sobie rzeczywistość w sobie tylko właściwy sposób” (tamże, Do Czytelnika, s. 2). Ale to wymaga stosownego 
rozpoznania i powstrzymania się od ferowania pospiesznych rozstrzygnięć. Gdy dyskutujący z sobą partnerzy zdecydowanie się różnią między sobą, to odpowiednio prowadzona „dyskusja pomoże te niezgodności ujawnić, zrozumieć i w rezultacie zaakceptować”, a „napięcie polemiczne wyzwoli po każdej ze stron źródła nowych pomysłów" (tamże, s. 145).

W dyskusji - co podkreśla Roman Ingarden w rozprawce $O$ dyskusji owocnej słów kilka, zamieszczonej też w Książeczce o człowieku - niezbędna jest „swoboda wewnętrzna”, a jest ona „rzetelna, jeżeli jest wszechstronna [...] i jeżeli pozwala przezwyciężyć wszelkie nasze, na ślepo żywione przez nas przywiązanie do pewnych idei czy wartości. Ma być [...] wszechstronna, to znaczy, że ma się odnosić nie tylko do cudzych [...] twierdzeń, lecz także do twierdzeń własnych uznanych już za prawdziwe i uzasadnione, czy choćby tylko do żywionych przez nas przeświadczeń" (1987, ss. 173-174). Uczestnicząc w dyskusji, w której prezentowane są odmienne stanowiska, i dążąc do zrozumienia interlokutora, który - tak jawnie, jak też i niejawnie - różni się w żywionych przez siebie przekonaniach, trzeba zawiesić niejako samorzutnie nasuwające się oceny jego stanowiska: „Bez zawieszenia tej oceny [cudzego stanowiska czy postawy] nie jesteśmy skłonni wysłuchać rzetelnie cudzej argumentacji ani zrozumieć, dlaczego ktoś inny uznaje pewne twierdzenie, które my uważamy za fałszywe, a występuje przeciw temu, które my reprezentujemy. Trafne i wierne zrozumienie cudzej myśli [...] jest pierwszym warunkiem dyskusji rzetelnej i naprawdę wolnej”. Konieczne jest też w dyskusji „uniezależnienie się od naszych własnych przyzwyczajeń intelektualnych, a przede wszystkim, [...] wyzwolenie się z automatyzmu własnego języka, własnej aparatury pojęciowej. Jest to bowiem niezbędny wstęp do tego, by podjąć próbę i wysiłek (nieraz znaczny) zrozumienia cudzego języka i aparatury pojęciowej" (tamże, s. 174). Jeśli nie ma w nas swobody wewnętrznej względem własnych językowych przyzwyczajeń, to język, który „ma być środkiem do porozumienia się i do uzyskania zgody na te same twierdzenia, staje się zaporą nieraz nie do przebycia. [...] [zaporą] także dla dotarcia rzeczywistości widzianej i ujmowanej językowo przez kogo innego" (tamże, s. 175). Trzeba niejako wyjść z siebie w dyskusji, wyjść z ram własnego językowego obrazu świata, bo „trzymanie się z uporem własnego języka, własnego sposobu rozumienia, własnego wartościowania - to właśnie ów brak swobody wewnętrznej, który iluzoryczną czyni wszelką próbę dyskusji między ludźmi" (tamże, s. 175). Potrzeba wypracowania swobody wewnętrznej owocnej dyskusji jeszcze szczególnie istotna i zarazem trudna w dyskusjach międzykulturowych. 
Przyjęcie postawy życzliwości - a także kierowanie się sformułowaną na gruncie filozofii analitycznej zasadą życzliwości (principle of charity) ${ }^{16}$ - stanowi jeden z podstawowych i niezbędnych warunków dyskusji, która pozwala uzyskać lepszą wiedzę o dyskutowanych poglądach. W rozwiniętej, usystematyzowanej i wartej przytoczenia postaci zastosowanie zasady życzliwości w dyskusji przedstawił Leon Koj:

„Dyskusja naukowa, wbrew pozorom, musi odznaczać się życzliwością dyskutantów wobec siebie. Jest to warunek wzajemnego zrozumienia, gdy wyznają odmienne poglądy. Różne przekonania są związane z różnymi modelami interpretacyjnymi wyrażeń języka. Aby zrozumieć wypowiedzi dyskutanta o odmiennych poglądach, trzeba szukać modelu, którym się on posługuje. W tym celu trzeba budować model dla nas fikcyjny, [...] taki fikcyjny model pozwala interpretować wypowiedzi dyskutanta i tym samym umożliwia rozumienie jego wypowiedzi. Gdy nie zdobędziemy się na wysiłek zbudowania fikcyjnego dla nas modelu, jedyną metodą nadania wypowiedziom dyskutanta znaczenia jest taki lub inny przekład na nasz język i interpretacja ich w naszym modelu. Wtedy jednak z reguły wypowiedzi przeciwnika w dyskusji nabiora mniej lub więcej karykaturalnego charakteru. Jedyną skuteczną motywacją dla trudu budowania fikcyjnego modelu może być tylko życzliwość dla dyskutanta, wiara, że nie jest on pozbawiony całkowicie racji, chęć dotarcia do jego wizji świata po to, aby ukazać mu w jego języku wartość naszego obrazu świata" (1993, ss. 71-72).

Podejmowanie się budowania fikcyjnego modelu wydaje się szczególnie istotne $\mathrm{w}$ relacjach międzykulturowych, $\mathrm{z}$ tej też racji warte jest przemyślenia i przyswojenia na gruncie edukacji międzykulturowej.

Jeśli przystać na proponowane przez Leona Koja ujęcie nauki i nauczania, w którym „dyskusja jest fundamentem twórczości w nauce, jest źródłem jej rozwoju" (1993, s. 38) ${ }^{17}$, a odpowiednio do przyjętego rozumienia nauki

16 Zob. zwięzłą jej prezentację w haśle: Życzliwości zasada (autor U. Tietz) zawartym w Leksykonie pojęć filozofii analitycznej (P. Prechtl, 2009, ss. 319-320).

17 „Mimo zgody z relatywistami, że żadna metoda ani żaden zespół metod nie może być uznany za gwaranta trafności poznania naukowego i jego zbliżania się do prawdy, twierdzimy, że posiadamy zabezpieczenie przyszłego racjonalnego poznania ludzkiego. Tym zabezpieczeniem jest dyskusja naukowa [...]. Dyskusje te zakładają racjonalność dyskutantów, a nie racjonalność metod. Metody już uznane są racjonalne w sposób wtórny: są o tyle racjonalne, o ile zostały wypracowane w dyskusji naukowej i o ile racjonalni są dyskutanci. Kartezjanizm był próbą oparcia racjonalności na regu- 
„nauczanie oprócz wiedzy musi wpoić umiejętność rzetelnego dyskutowania" (1993, s. 38) ${ }^{18}$, to uprawianie edukacji międzykulturowej powinno być w szczególności otwarte nad dyskusje i powinno też z różnych punktów widzenia wnikliwie rozpatrywać i wypracowywać koncepcje dyskusji jako uprzywilejowanej formy poznania (wzajemnego poznawania się) w relacjach międzykulturowych.

\section{O inspirowaniu się fenomenologią obcości i obcego w edukacji międzykulturowej}

Edukacja międzykulturowa w swych badaniach może - a nawet w niektórych przypadkach powinna - inspirować się fenomenologią obcości i obcego, którą rozwinął i w systematycznej postaci przedstawił Bernhard Waldenfels. Wyjaśniając podstawowe motywy fenomenologii obcego, Bernhard Waldenfels przybliża zasadnicze nastawienie fenomenologii obcego: „Obce jako obce wymaga responsywnej formy fenomenologii, która zaczyna od tego, co w szokujący, zdumiewający albo przerażający sposób rzuca nam wyzwanie, kusi nas, wywołuje i kwestionuje nasze własne możliwości, zanim jeszcze pojawi się u nas problematyzująca chęć wiedzy i zrozumienia. Patos obcego dominuje nad jego problematycznością" (2009, ss. 55-56). Fenomenologiczna analiza obcego i obcości wymaga właściwej fenomenologii postawy badawczej, próby kontaktu z „rzeczą" tak jak ona jest dana, bez narzucania jej dogodnej dla nas - a dość radykalnie redukującej ją - formy badawczej: „Gdyby doświadczenie obcego było czymś, co wywołujemy w sposób celowy i metodyczny, to obce znowu byłoby rezultatem pochodzącym z naszych własnych przedsięwzięć i podlegającym naszym własnym miarom. Obce, które sprawia, że tracimy

łach i metodach, gdyż kwestionował racjonalność ludzi. Jednak to ludzie w rzetelnych dyskusjach wykrywają lub formułują reguły właściwego postępowania” (Koj, 1993, s. 35). „Metodologia pozytywistyczna nie zajmuje się metodami współpracy badaczy. Wszystkie reguły są tak opisane, że może je wykonać jedna osoba. W ten sposób pozytywiści stali się kontynuatorami kartezjańskiego indywidualizmu" (tamże, s. 69).

$18 \ldots[\ldots]$ nie dajemy studentom prawie żadnej możliwości zdobycia umiejętności rzetelnego dyskutowania. Skutkiem tego kwitnie indywidualizm w postaci najgorszej, czyli zamykania się w sobie. [...] Jeśli mamy opanować umiejętność dyskutowania, trzeba po prostu dużo dyskutować. Przy czym muszą to być dyskusje tak przeprowadzone, że mogą służyć jako wzorce godne naśladowania. Chodzi więc o praktykę w rzetelnych dyskusjach, a nie w bezwładnych utarczkach słownych, które nie tyle kształcą, co demoralizują. Na uczelni jest mało okazji do dyskutowania w trakcie procesu nauczania" (Koj, 1993, s. 75). 
panowanie nad sobą i przekraczamy granice danego porządku, nie może być czymś, co samodzielnie wywołujemy. Da się pomyśleć tylko jako patos, który nam się przydarza. Ambiwalencja tkwiąca w tym słowie i zawierająca w sobie cierpienie, strzeże nas przed niewinnym tłumaczeniem obcego. [...] Odpowiadanie na obce ma znaczenie czegoś więcej niż tylko sensownego rozumienia, więcej, niż porozumienia kierowanego normami, jakkolwiek by to wszystko było ważne. Doświadczenie interkulturowe rozwadnia się przybierając postać cienkiego interkuturalizmu [...]" (2009, ss. 128-129). Uwagi krytyczne o postaciach „cienkiego interkuturalizmu” bliskie są krytycznym odniesieniom edukacji międzykulturowej do programów multikulturalizmu.

Rozpatrując topografię obcego, Bernhard Waldenfels zwraca uwagę na odkrywanie obcości w sobie (własnej obcości), jako warunku rzetelnego rozpoznawania tego, co jawi się nam obcym: „Obce nie jawiłoby się już jako coś, co oczekuje, by je przyswoić, lecz jako coś, co jest wykluczone przez rozmaite porządki i właśnie dzięki temu wyróżnione jako nad-zwyczajne, jako zarazem pre- i transkulturowe, wędrujące przez kultury i wznoszące się ponad nie. Obcość interkulturowa znajduje przy tym oddźwięk w obcości intrakulturowej, wyrastającej z obcości naszego własnego pochodzenia. Tam, gdzie ten oddźwięk milknie, obcość innego redukuje się do czystej egzotyki, do tego, co własne z odwróconym znakiem" (2002, s. 152). Trzeba więc niejako wpierw odkrywać „obcość własnego pochodzenia”, aby być otwartym na rozpoznawanie innej obcości, której nie zredukuje się do jedynie egzotyczności.

\section{Zakończenie. O potrzebie kontynuowania badań semiotycznych w edukacji międzykulturowej (w aspekcie teoretycznym i praktycznym)}

Teoria i praktyka działań pedagogicznych są w dużej mierze oparte na teorii i praktyce działań językowych. Dlatego na zakończenie wyeksponowania wymaga potrzeba dalszego wypracowywania semiotyczno-metodologicznych rozróżnień w języku edukacji międzykulturowej; zwłaszcza że heurystycznie płodne są dywagacje dotyczące kształtowania języka relacji międzykulturowych. Ale także trzeba rozpoznać - a nawet zrewidować założenia antropologiczne - przyjmowane u podstaw pojęć zespolonych z wielokulturowością, co postuluje m.in. Jerzy Nikitorowicz: „Uważam, że w warunkach współczesnej wielokulturowości zagubiony został wielowymiarowy, samosterowalny, twórczy człowiek, a jego najbardziej istotne cechy zostały »uwięzione« [...] i wrażliwość zmarginalizowana. Nie wyprowadzono z nich norm zachowa- 
nia i działań w tym zakresie, nie wdrożono wiedzy i pozytywnych emocji do działań edukacyjnych i w efekcie nie ukształtowano twórczych, innowacyjnych postaw" (2013, s. 113). Nie tylko treść pojęć, ale przyjmowane założenia wymagają analiz i korekt.

Przykładem wątpliwości i dylematów teoretycznych dotyczących podstawowych kategorii spożytkowanych i interpretowanych w edukacji międzykulturowej są podstawowe kategorie: tożsamości ${ }^{19}$ i podmiotowości, a także pluralizmu i tolerancji ${ }^{20}$. Uwzględnienia wymagają także trudności w trafnym przekładzie tych pojęć (np. różnice między językiem polskim a językiem angielskim). Podstawowe pojęcia edukacji międzykulturowej nie są dostatecznie jasne, jak zauważa Andrzej Sadowski: „używanie pojęcia wielokulturowości w praktyce wymyka się [...] naukowej kontroli, staje się kluczem-wytrychem do nazywania bardzo różnorodnych stanów, rzeczy, zjawisk i procesów społeczno-kulturowych" (2010, s. 103) ${ }^{21}$. Należy więc uporządkować sposób posługiwania się kluczowymi pojęciami. Wyraźnie zarysowuje się tu kwestia - pożądanego stopnia - jasności, ścisłości i precyzji wywodu w edukacji międzykulturowej. Niezbędne jest rozeznanie roli terminów nasyconych emocjonalnie oraz metaforycznych określeń w edukacji międzykulturowej.

Refleksja metodologiczna i analiza semiotyczna towarzysząca ksztaltowaniu w ramach edukacji międzykulturowej w jakimś zakresie nowego języka, służącego efektywnej komunikacji międzykulturowej, języka, który przezwycięża dotychczasowe niedobory komunikacyjne. Edukacyjny wymiar analizy semiotycznej a kształtowanie w ramach edukacji międzykulturowej kompetencji komunikacyjnych użytkowników tego nowego języka, zwłaszcza pedagogów.

Rola opozycji w siatce pojęciowej edukacji międzykulturowej. Przykładem, jak pracują opozycje w siatce pojęciowej edukacji międzykulturowej, jest fragment wywodu Ewy Ogrodzkiej-Mazur: „Doświadczenie »małej ojczyzny« uświadamia bowiem istnienie szerokiego »świata zewnętrznego«, jako szczególnej opozycji ograniczenia świata »swoich «. Elementy te - tworzące strukturę i jakość edukacji międzykulturowej - są zatem nieodzowne w procesie wychowania i kształcenia" (2012, s. 214). Warto bliżej rozpatrzeć

19 W kwestii tożsamości w odniesieniu do badań edukacji międzykulturowej zob. E. Ogrodzka-Mazur, 2001.

20 W kwestii tolerancji w odniesieniu do badań edukacji międzykulturowej zob. E. Ogrodzka-Mazur, 1998.

21 O trudnościach i dylematach związanych z wielokulturowością (opcjach/argumentach za i przeciw) zob. B. Szlachta, 2010, ss. 17-23; A. Szahaj, 2010, ss. 25-30. 
rolę różnego rodzaju opozycji w siatce pojęciowej edukacji międzykulturowej.

Należy także odnotować praktyczny (pozytywny) wymiar uzgodnienia pojęć w relacjach międzykulturowych, na co uwagę zwraca m.in. Andrzej Grzegorczyk: „W obecnej sytuacji podziałów ludzkości - podziałów, które prowadzą do bardzo groźnych i wyniszczających konfliktów zbrojnych, uzyskanie wspólnego systemu pojęć podstawowych wydaje się bardzo ważnym tematem współpracy intelektualnej ludzi różnych narodów i kultur. Wszelka umowa międzynarodowa, umowa społeczna, polityczna czy międzykonfesyjna, której nie towarzyszy wspólne rozumienie pojęć, jest powierzchowna i nietrwała. Może być zerwana w każdej chwili, gdy jedna ze stron stwierdzi, że inaczej rozumie pojęcia użyte niż strona druga. Ludzka "poznawcza« regulacja zachowania wyraźnie daje tu znać o sobie" (2001, s. 167). Wypracowanie wspólnego rozumienia pojęć pozwala na bardziej efektywne współdziałanie, które zmierza do wspólnie uzgodnionych celów, uznanych za stany rzeczy warte urzeczywistniania.

Postulat słownika (leksykonu) edukacji międzykulturowej. Jego opracowanie będzie zarazem próbą namysłu i uporządkowania podstawowych pojęć służących do formułowania teorii i zaleceń praktycznych edukacji międzykulturowej. W słowniku trzeba będzie m.in. wykazać podobieństwa i różnice między terminologią właściwą dla edukacji wielokulturowej a terminologią właściwą dla edukacji międzykulturowej (wraz z jej założeniami antropologicznymi i aksjologicznymi), jak również odmienności terminologiczne między psychologią relacji międzykulturowych, socjologicznym, politologicznym i ekonomicznym (nauki o zarządzaniu) oraz prawnym namysłem nad sytuacją relacji międzykulturowych a edukacją międzykulturową. Powinno się też uwzględnić terminologię z dyskusji etyków i filozofów dotyczących relacji międzykulturowych. Przy pracach nad tym słownikiem można się odwołać także do projektu słownika, który (w innym obszarze tematycznym) przedłożył Jerzy Bartmiński (1996): „Słownik jest pomyślany jako intensywny, a nie ekstensywny, tzn. przedstawia szczegółowiej wybrane, ważne hasła, dając ich »portrety « językowo-kulturowe, a nie skrótowo i pobieżnie wszystkie hasła wyrazowe, pojawiające się w badanych tekstach [...]"22. Wedle takich zasad projektowany słownik edukacji międzykulturowej

22 „Układ materiału w Stowniku wedle pól leksykalno-semantycznych pozwala unaocznić hierarchię haseł poprzez ich odpowiednie pogrupowanie. Dodatkowo odpowiednie hasła łączy się w stosownych miejscach odsyłaczami” (tamże). 
powinien być niejako wyrazem samoświadomości pojęciowej tej dziedziny pedagogiki.

\section{Bibliografia}

Bartmiński, J. 1996. O „Słowniku stereotypów i symboli ludowych”. W: Słownik stereotypów i symboli ludowych. T. 1. Cz. 1. Lublin: UMCS, ss. 9-34; http://www.rastko.rs/projekti/etnoling/delo/12018.

Bińczycka, E. 2012. Technonauka w społeczeństwie ryzyka. Filozofia wobec niepożadanych następstw praktycznego sukcesu nauki. Toruń: UMK.

Chmielewski, A. 1998. Relatywizm: zagrożenia czy szansa? Etyka. 31, ss. 28-58 .

Chmielewski, A. 2014. Niewspótmierność, nieprzektadalność, konflikt. Relatywizm we współczesnej filozofii analitycznej. Wrocław: UW.

Czeżowski, T. 1958. O kulturze logicznej (napisane w 1954 r.). W: Odczyty filozoficzne. Toruń - Łódź: Państwowe Wydawnictwo Naukowe, ss. 271-279 .

Czeżowski, T. 1977. Wspomnienia (zapiski do autobiografii). Kwartalnik Historii Nauki i Techniki. 22:3, ss. 427-440.

Dąmbska, I. 1930. W sprawie nauczania logiki przy sposobności nauczania języka polskiego. Przegląd Klasyczny. 3, ss. 279-287.

Dąmbska, I. 1977. Tadeusz Czeżowski - jedność dzieła i osobowości. Kwartalnik Historii Nauki i Techniki. 22:1, ss. 21-26.

Elzenberg, H. 1994. Kłopot z istnieniem: aforyzmy w porzadku czasu. Kraków: Społeczny Instytut Wydawniczy Znak.

Grzegorczyk, A. 1993. Życie jako wyzwanie. Wprowadzenie w filozofię racjonalistyczną. Warszawa: IFiS PAN.

Grzegorczyk, A. 2001. Europa. Odkrywanie sensu istnienia. Warszawa: UKSW.

Heller, M. 2009. Jak być uczonym. Kraków: Społeczny Instytut Wydawniczy Znak.

Ingarden, R. 1987. O dyskusji owocnej słów kilka. W: Ingarden, R. Książeczka o człowieku. Kraków: WL, ss. 173-176.

Kamiński, S. 1962. O uzasadnianiu tez filozoficznych. Roczniki Filozoficzne. 3, ss. 37-65.

Kamiński, S. 1993. Filozofia i metoda. Studia z dziejów metod filozofowania. Lublin: KUL. 
Kleszcz, R. 2002. Tadeusz Czeżowski o przekonaniach, wiedzy i wierze. W: Tyburski, W. i Wiśniewski, R. red. Tadeusz Czeżowski (1889-1981). Dziedzictwo idei: logika - filozofia - etyka. Toruń: UMK, ss. 67-78.

Koj, L. 1993. Watpliwości metodologiczne, seria: Realizm. Racjonalność. Relatywizm t. 16. Lublin: UMCS.

Koj, L. 1998. Zdarzeniowa koncepcja znaku. Warszawa: Polskie Towarzystwo Semiotyczne.

Korporowicz, L. 1997. Wielokulturowość a międzykulturowość: od reakcji do interakcji. W: Łodziński, S., Kempny, M. i Kapciak, A. red. U progu wielokulturowości. Nowe oblicza spoteczeństwa polskiego. Warszawa: Oficyna Naukowa, ss. 64-72.

Kotarbiński, T. 1993. Filozofia a humanistyka (pierwodruk 1972). W: Kotarbiński, T. Ontologia, teoria poznania i metodologia nauk. Wrocław - Warszawa - Kraków: Zakład Narodowy im. Ossolińskich.

Lewowicki, T. 2001. Szkic do teorii zachowań tożsamościowych. W: Lewowicki, T. i Ogrodzka-Mazur, E. red. W poszukiwaniu teorii przydatnych w badaniach międzykulturowych. Cieszyn: UŚ - Filia w Cieszynie, ss. 159-165.

Lewowicki, T. i Ogrodzka-Mazur, E. 2001. Wprowadzenie. W: Lewowicki, T. i Ogrodzka-Mazur, E. red. W poszukiwaniu teorii przydatnych $w$ badaniach międzykulturowych. Cieszyn: UŚ - Filia w Cieszynie, ss. 11-13.

Łukasiewicz, D. 2002. Filozofia Tadeusza Czeżowskiego. Bydgoszcz: Akademia Bydgoska im. Kazimierza Wielkiego.

Marciszewski, W. 1994. Sztuka dyskutowania. Warszawa: „Aleph”.

Melosik, Z. 2007. Teoria i praktyka edukacji wielokulturowej. Kraków: Oficyna Wydawnicza „Impuls”.

Mysłakowski, Z. 1971. Umiejętność różnienia się - o tolerancji. W: Nowacki, T. red. Zygmunt Mysłakowski. Pisma wybrane. Warszawa: PZWS, ss. $245-248$.

Nikitorowicz, J. 2012. Fenomen wielokulturowości i prognozy rozwoju ku międzykulturowości. Edukacja Międzykulturowa. 1, ss. 45-66.

Nikitorowicz, J. 2013. Konsekwencje wielokulturowości dla tożsamości jednostkowej i kultury narodowej. W: Dyczewski, L. i Jurek, K. red. Tożsamość w wielokulturowym kontekście. Lublin - Warszawa: Wydawnictwo KUL, Centrum Europejskie Natolin, ss. 109-118.

Nikitorowicz, J. 2014. Wielokulturowość - Pogranicze - Człowiek pogranicza. Ku paradygmatowi współistnienia, zachowania i kreowania pokoju. 
Drohiczyński Przeglad Naukowy. Wielokulturowe Studia Drohiczyńskiego Towarzystwa Naukowego. 6, ss. 171-189.

Nikitorowicz, J. 2015. Ku jakim strategiom w edukacji międzykulturowej w kontekście współczesnych problemów wielokulturowości. Pogranicze. Studia Społeczne, t. XXV, ss. 25-40.

Nowak, M. 2012. Pedagogiczny profil nauk o wychowaniu. Studium z odniesieniami do pedagogiki pielegniarstwa. Lublin: KUL.

Ogrodzka-Mazur, E. 1998. Tolerancja jako wartość w procesie edukacji wielokulturowej. W: Lewowicki, T. i Grabowska, B. red. Młodzież i tolerancja (studium z pogranicza polsko-czeskiego). Cieszyn: UŚ - Filia w Cieszynie, ss. 82-98.

Ogrodzka-Mazur, E. 2001. Kategoria tożsamości w analizach zmiany społecznej. Implikacje pedagogiczne do badań edukacji międzykulturowej. W: Lewowicki, T. i Ogrodzka-Mazur, E. red. W poszukiwaniu teorii przydat$n y c h w$ badaniach międzykulturowych. Cieszyn: UŚ - Filia w Cieszynie, ss. 55-68.

Ogrodzka-Mazur, E. 2012. Edukacja międzykulturowa. Recenzja: Pogranicze. Studia Społeczne, t. XVII, cz. 1, Białystok 2011, red. Nikitorowicz, J., Sadowski, A. i Misiejuk, D. Edukacja Międzykulturowa. 1, ss. 212-215.

Popper, K. R. 1997a. Logika nauk społecznych. W: Popper, K. R. W poszukiwaniu lepszego świata. Wykłady i rozprawy z trzydziestu lat. Warszawa: KiW, ss. 82-101.

Popper, K. R. 1997b. O zderzeniu kultur. W: Popper, K. R. W poszukiwaniu lepszego świata. Wykłady i rozprawy z trzydziestu lat. Warszawa: KiW, ss. $139-148$.

Popper, K. R. 1997c. Przeciwko wielkim stowom (List, który pierwotnie nie byt przeznaczony do publikacji). W: Popper, K. R. W poszukiwaniu lepszego świata. Wyktady i rozprawy z trzydziestu lat. Warszawa: KiW, ss. 102-116. Popper, K. R. 1999. Utopia a przemoc. W: Popper, K. R. Droga do wiedzy. Domysty i refutacje. Warszawa: PWN, ss. 590-604.

Prechtl, P. 2009. Leksykon pojęć filozofii analitycznej. Kraków: WAM.

Sadowski, A. 2010. Edukacja międzykulturowa jako nabywanie kompetencji do życia w społeczeństwie pluralistycznym. W: Lewowicki, T. i Ogrodzka-Mazur, E. red. Edukacja międzykulturowa - teorie, poglady, doświadczenia społeczne. Cieszyn - Warszawa - Toruń: Wydział Etnologii i Nauk o Edukacji Uniwersytetu Śląskiego, Wyższa Szkoła Pedagogiczna ZNP w Warszawie, Stowarzyszenie Wspierania Edukacji Międzykulturowej, Adam Marszałek, s. 103. 
Sitek, W. 2010. Paradygmaty, aporie i instytucjonalizacja socjologii w kontekście twórczości Floriana Znanieckiego. W: Hałas, E. i Kojder, A. red. Socjologia humanistyczna Floriana Znanieckiego. Przesłanie dla wspótczesności. Warszawa: WUW, ss. 133-142.

Stępień, A. B. 1995. Wstęp do filozofii. Lublin: KUL.

Stróżewski, W. 1992. Ponadkulturowe wymiary dobra, prawdy i piękna. W: Stróżewski, W. W kręgu wartości. Kraków: Społeczny Instytut Wydawniczy Znak, ss. 108-132.

Szahaj, A. 2010. Wielokulturowość: za i przeciw (kilka uwag). W: Pietrzyk-Reeves, D. i Kułakowska, M. red. Studia nad wielokulturowościa. Kraków: Księgarnia Akademicka, ss. 25-30.

Szlachta, B. 2010. Kłopoty z wielokulturowością. W: Pietrzyk-Reeves, D. i Kułakowska, M. red. Studia nad wielokulturowością. Kraków: Księgarnia Akademicka, ss. 17-23.

Szulakiewicz, W. 2014. Tadeusz Czeżowski - nauczyciel w stużbie uniwersytetu. W: Szulakiewicz, W. O uczacych i uczonych. Szkice z pedeutologii historycznej. Toruń: UMK, ss. 147-194.

Śliwerski, B. 2014. Czas na rozwój metapedagogiki. W: Denek, K., Kamińska, A. i Oleśniewicz, P. red. Edukacja jutra. Od tradycji do nowoczesności. Aksjologia w edukacji jutra. Sosnowiec: Wyższa Szkoła Humanitas, ss. $49-74$.

Śliwerski, B. 2015. Nauki o wychowaniu a pedagogika. Nauki o Wychowaniu. Studia Interdyscyplinarne. 1, ss. 14-41.

Śliz, A. 2009. Wielokulturowość: iluzje czy rzeczywistość? Socjologiczne studium przypadku na przyktadzie Kongresu Polonii Kanadyjskiej. Opole: UO.

Śliz, A. i Szczepański, M. S. 2011. Wielokulturowość i jej socjologiczny sens. Festival Caravan czy wielokulturowe Street Party? Studia Socjologiczne. 4 (203), ss. 7-25.

Waldenfels, B. 2002. Topografia obcego. Studia $z$ fenomenologii obcego. Warszawa: Oficyna Naukowa.

Waldenfels, B. 2009. Podstawowe motywy fenomenologii obcego. Warszawa: Oficyna Naukowa.

Witkowski, L. 2007. Między pedagogika, filozofia i kulturą. Studia, eseje, szkice. T. III. Warszawa: IBE.

Wolak, Z. 1994. Rola dyskusji w rozwoju nauki. Recenzja: Leon Koj, Watpliwości metodologiczne (seria: Realizm. Racjonalność. Relatywizm t. 16, Wydawnictwo Uniwersytetu Marii Curie-Skłodowskiej, Lublin 1993). Zagadnienia Filozoficzne w Nauce. 16, ss.127-129. 
Ziemińska, R. 2009. Spór relatywizmu z absolutyzmem na temat pojęcia prawdy. Roczniki Filozoficzne. T. LVII, 1, ss. 299-314. Życiński, J. 1990. Trzy kultury. Nauki przyrodnicze, humanistyka i myśl chrześcijańska. Poznań: „W drodze”.

\section{Intellectual culture, methodological doubts and metapedagogical reflection in developing the theory and practice of intercultural education}

Abstract: The concern for intellectual culture seems to be one of elementary dimensions in the reliable development of the theory and practice of intercultural education. The care for improving intellectual culture - both in the individual dimension (acquiring and developing cognitive skills) and the social one (especially in the field of scientific work) - mostly pertains to developing logical culture and deepening the methodological reflection, which raises doubts and allows for critical recognition of research problems. In the approach to intellectual culture presented by Tadeusz Czeżowski in the lecture "On logical culture", intellectual culture is interrelated with the theory and practice of intercultural education because "it lifts people above the oppositions which divide them and connects them by the bonds of general human solidarity".

In this way, intellectual culture enables achieving the goals which are also aimed at in intercultural education. Shaping intellectual culture, treated as making a person "sensitive to the truth and falsehood, to the correctness of thinking and logical errors", refers straight to the issue, discussed within intercultural education, of the radicalizing relativism, which suppresses other approaches and doubts in the valuing of the truth and in the aptness of the criteria of correct thinking which refer to it. Some questions might be raised: Is Czeżowski's understanding of intellectual culture (with its assumed universality) not a form of (hidden) cultural imperialism in the sphere of the valuing of knowledge and education? Is this not an attempt to impose a particular set of values as self-evident and binding ones? Is it possible to prove in a justifiable and convincing way that there are some common elements of intellectual culture in various, much different, cultural formations - the elements of equally crucial significance in educational traditions which are unfamiliar to each other? Is the presented understanding of intellectual culture (as the morally binding logical culture) only a manifestation of one of many local cultural formations though it shows itself (along with the rules of logic) as something important and self-understandable or even something written into the human nature or human mind? These and similar queries are formulated here as one of the properties of intercultural education is that it enters borderlands, where 
differences get in touch, and that it questions (perceives, as other comparative cultural studies do, as arguable) what in other fields of educational studies has been treated as inviolable obviousness of a particular culture, which as a kind of certainty is not subjected to any discussion.

Keywords: theory of intercultural education, intellectual culture, methodological doubts, metapedagogical reflection, relativism, logical culture

Translated by Agata Cienciała 